INTERNATIONAL MONETARY FUND

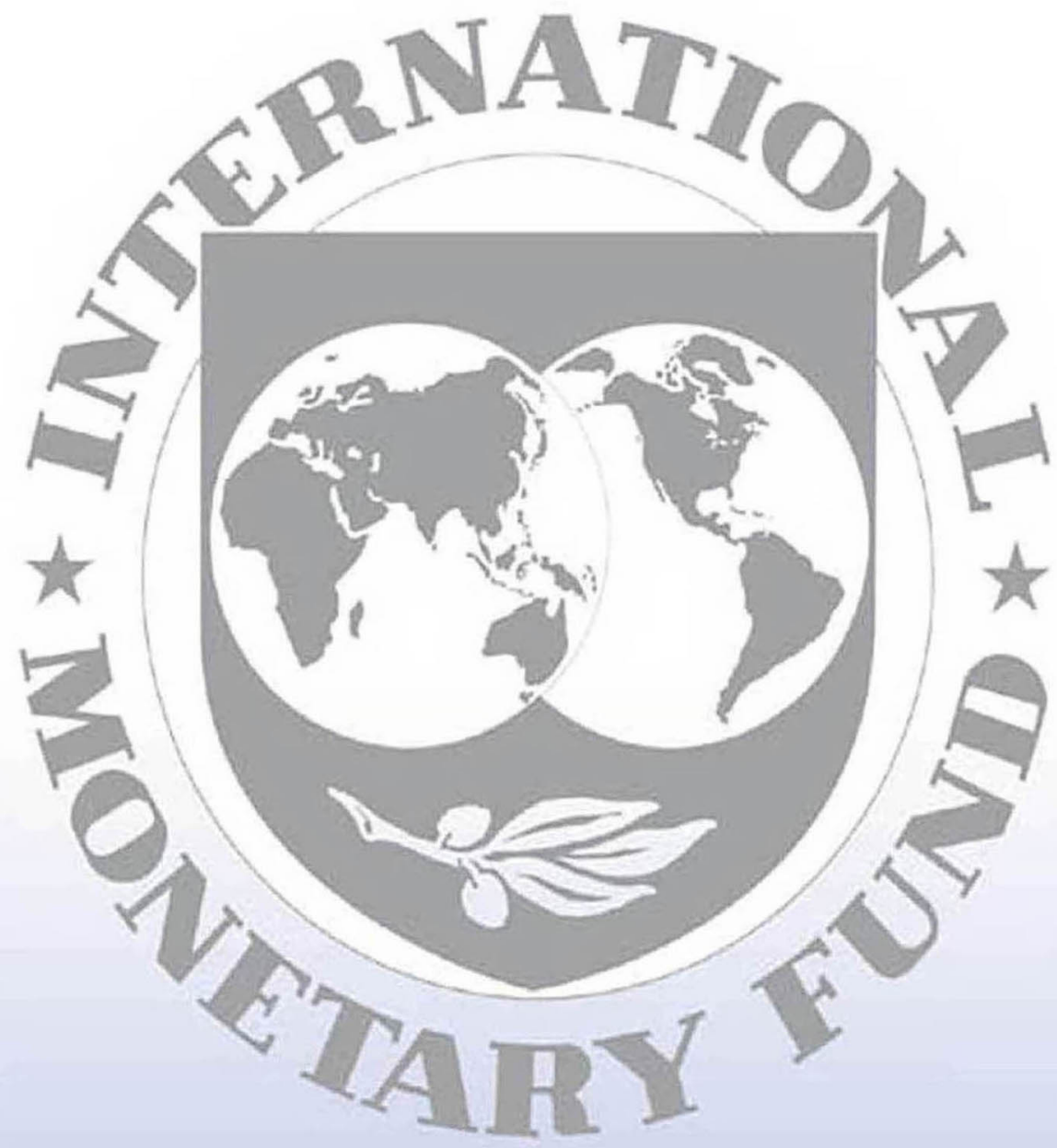

Staff

Country
Reports 


\section{Indonesia: CPSS Core Principles for Systemically Important Payment Systems}

This paper was prepared based on the information available at the time it was completed on November 2010. The views expressed in this document are those of the staff team and do not necessarily reflect the views of the government of Indonesia or the Executive Board of the IMF.

The policy of publication of staff reports and other documents by the IMF allows for the deletion of market-sensitive information.

Copies of this report are available to the public from

International Monetary Fund $\bullet$ Publication Services

700 19th Street, N.W. • Washington, D.C. 20431

Telephone: (202) 623-7430 • Telefax: (202) 623-7201

E-mail: publications@imf.org • Internet: http://www.imf.org

\section{International Monetary Fund \\ Washington, D.C.}




\section{FINANCIAL SECTOR ASSESSMENT PROGRAM INDONESIA}

CPSS CORE PRINCIPLES FOR SYSTEMICALLY IMPORTANT PAYMENT SYSTEMS

\section{DETAILED ASSESSMENT OF OBSERVANCE}

NOVEMBER 2010

THE WORLD BANK

FINANCIAL AND PRIVATE SECTOR DEVELOPMENT VICE PRESIDENCY EAST ASIA AND PACIFIC REGION VICE PRESIDENCY
INTERNATIONAL MONETARY FUND

MONETARY AND CAPITAL MARKETS

DEPARTMENT 


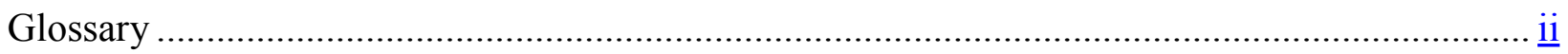

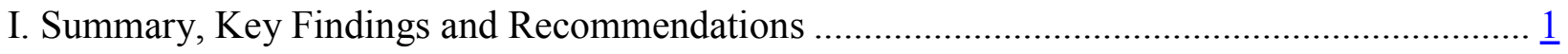

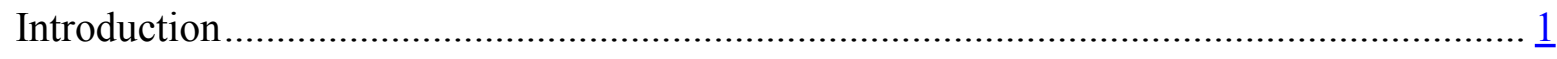

Information and methodology used for assessment....................................................... 1

Institutional and market structure …............................................................................. 2

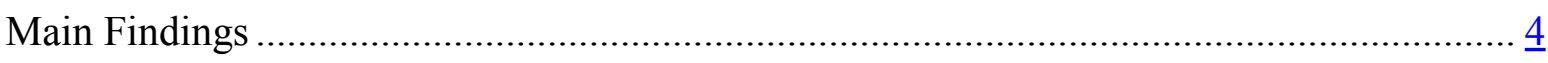

Recommended Actions and Authorities Response ………….............................................. 9

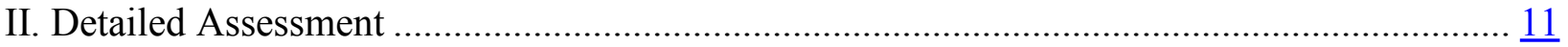

\section{Text Tables}

Table 1 Summary Observance of the CPSIPS and Central Bank Responsibilities in Applying the CPs - ROSCs ..........................................................................................

Table 2 Recommended Actions to Improve Observance of the CPSIPS and

Central Bank Responsibilities in Applying the CPs-BI-RTGS................................................. 9

Table 3 Summary observance of CPSS Core Principles and Central Bank Responsibilities in applying the $\mathrm{CPs}$-Detailed Assessments

Table 4 Detailed Assessment of BI-RTGS Observance of the CPSS CPSIPS and the BI Responsibilities in Applying the CPSIPS 


\section{GLOSSARY}

$\begin{array}{ll}\text { ATM } & \text { Automated Teller Machine } \\ \text { BI } & \text { Bank Indonesia } \\ \text { BI-RTGS } & \text { Bank Indonesia Real Time Gross Settlement System } \\ \text { BI-SSSS } & \text { Bank Indonesia Scripless Securities Settlement System } \\ \text { Bapepam-LK } & \text { Capital Market and Financial Institution Supervisory Agency } \\ \text { CP } & \text { Core Principle } \\ \text { CPSIPS } & \text { Core Principles for Systemically Important Payment Systems } \\ \text { CPSS } & \text { Committee on Payment and Settlement Systems } \\ \text { DASP } & \text { Directorate of Accounting and Payment Systems } \\ \text { DR } & \text { Disaster Recovery } \\ \text { DVP } & \text { Delivery versus Payment } \\ \text { FSAP } & \text { Financial Sector Assessment Program } \\ \text { HKD } & \text { Hong Kong Dollar } \\ \text { HKMA } & \text { Hong Kong Monetary Authority } \\ \text { IMF } & \text { International Monetary Fund } \\ \text { MOU } & \text { Memorandum of Understanding } \\ \text { PVP } & \text { Payment versus Payment } \\ \text { Rp } & \text { Rupiah } \\ \text { RTGS } & \text { Real Time Gross Settlement } \\ \text { SKNBI } & \text { Sistem Kliring Nasional Bank Indonesia (Bank Indonesia's National Clearing } \\ & \text { System) } \\ \text { SLA } & \text { Service Level Agreement } \\ \text { SNA } & \text { Systems Network Architecture } \\ \text { SRO } & \text { Self Regulation Organization } \\ \text { SWIFT } & \text { Society for Worldwide Interbank Financial Telecommunication }\end{array}$




\section{SUMMARY, KEY FINDINGS AND RECOMMENDATIONS}

\section{Introduction}

1. This assessment forms part of the joint International Monetary Fund (IMF) and World Bank Indonesia Financial Sector Assessment Program (FSAP) which is being undertaken during 2009-2010. The assessment which covers the Bank Indonesia's real time gross settlement (BI-RTGS) system's observance of the CPSS Core Principles for Systemically Important Payment Systems (SIPS) and the Central Bank's Responsibilities in applying the Core Principles was conducted during the first mission (6-16 October 2009).

\section{Information and methodology used for assessment}

2. The assessment which was conducted with the cooperation of the Bank Indonesia and other key players in the payment systems area was undertaken by Alice Zanza, Senior Payment Systems Specialist, World Bank with the assistance of Bruce Summers, Senior Payment Systems Advisor, World Bank. Although there are several systems in operation in Indonesia, BI considers the Bank Indonesia Real Time Gross Settlement (BI-RTGS) system to be the only systemically important payment system in the country. BI-RTGS is owned by BI and operated by the Payment Systems Department in the Directorate of Accounting and Payment Systems. To date, the assessment team does not have any information to expand the scope of systemically important payment systems in Indonesia and has conducted the assessment of the RTGS system, as the sole SIPS in the country.

3. The sources of information gathered during the course of this assessment were varied, and included interviews held with relevant officials from the Bank Indonesia (BI); several participants in the BI-RTGS, bank and non bank; representatives of the Bankers Association; Artajasa, an ATM switching company with indirect participant status in BI-RTGS; the Bankers Association By- Laws Committee responsible for enforcing members' code of conduct in the BI-RTGS operations; the post office; telecommunications companies and mobile service providers.

4. Several documents were provided by the authorities prior to the commencement of the mission, including a detailed self-assessment of the BI-RTGS, and information posted on the website of BI. The other main sources of information were: (i) the BI Act 23 of 1999 (ii) Bankruptcy and Suspension of Obligation for Payment of Debts Act, (iii) various regulations, rules and circular letters relevant to the operations of payment systems and issued by $\mathrm{BI}$ in its capacity as the overseer of payment systems.

5. The tools used to assist and guide the assessors in achieving the objectives of this assessment were the standards report itself (-CPSS Core Principles for Systemically Important Payment Systems", January 2001) —Guidance Note for Assessing Observance of Core 
Principles for Systemically Important Payment Systems and the Structure and Scope of the Assessment Report" produced by the IMF and World Bank in collaboration with the Committee on Payment and Settlement Systems.

6. The assessors wish to express their appreciation to the BI, banking industry representatives and all the payment systems stakeholders for their cooperation and willingness to meet with the assessors at the times requested. Special appreciation must be expressed for the assistance rendered by the Accounting and Payment System Directorate (DASP) who were the assessors' main counterparts and facilitated follow up meetings within BI and externally.

\section{Institutional and market structure}

7. Bank Indonesia is at the apex of the payment system in Indonesia and is empowered by the BI Act 23 of 1999 to supervise banks and other financial institutions, conduct monetary policy and oversee the payments system. Using its spread of forty (40) branches BI facilitates interbank clearing and the distribution of cash throughout the country. BI also provides settlement in central bank money for the RTGS system it operates, the government securities system and the national clearing system.

8. The main players in the payment system in Indonesia are banks who comprise state banks, private banks, regional development banks and sharia banks. Most of these banks have a deliberate policy to extend payment services by establishing branches throughout the country.

9. Cash remains a dominant means of payment in Indonesia despite the various innovative products and instruments introduced by banks in the provision of payment services. According to available statistics, the cash utilization levels have maintained an upward trend over the last 6 years and reached the highest point in 2008. Other means of payment used in Indonesia include cheques, drafts, and direct debit and credit transfers. Various payment cards are issued by banks and these are switched through different networks which are not interlinked. The biggest of these networks (Artajasa) in terms of number of banks it services, has access to the BI- RTGS in order to facilitate settlement of card and other retail transactions by member banks.

10. The BI-RTGS system is the main system for handling payments, and is also used for the settlement of obligations arising from the other payment streams. The system was introduced in 2000 as part of BI's strategy to address risks inherent in the cheque clearing system, arising from the ever increasing volumes and values. The BI-RTGS links 149 participants to the central bank, using a designated network. The forty branches of BI connect to the system using the Bank's intranet. Of the 149 participants, 144 are banks of which 2 are indirect participants; the remaining 5 are non bank participants who include Artajasa (ATM switching company), Posindo (the post office), Lintas Arta (a switching company) Finnet (an emoney switching company) and more recently, the Indonesia Eximbank. The indirect participant 
status is offered to participants who handle small volumes; they are required to hold a demand deposit account at the BI.

11. BI RTGS settles transactions in real time, using central bank money. Participants to the system use a front end (provided for interfacing with BI), to input instructions that are sent through a dedicated network to the central bank's central system. Since the system works on a credit push basis, the settlement account has to be adequately funded before a transaction can be settled. Once a payment is successfully processed in BI-RTGS-one account debited and the other credited-it is deemed to be final and cannot be reversed. This position is clearly provided for in the BI-RTGS regulations.

\section{In the event that a settlement account is not adequately funded, payment} transactions are held in a queue until sufficient funds are available on the participant's account. Participants have the facility to manage outgoing payments held in queue, and prioritize them as appropriate. Items still held in the queue at the system cut off time are automatically cancelled.

\section{To facilitate settlement as well as ensure a smooth flow within the system, BI} provides a collateralized intraday credit facility to all bank participants. Participants are also encouraged to process their payments early in the day using the throughput guidelines provided. The system's pricing is designed around two windows with the first window being the cheapest (at $\operatorname{Rp~7,000~per~transaction)~to~encourage~early~payments.~The~second~window~which~}$ runs from $3 \mathrm{pm}$ to end of day attracts a fee of Rp 14,000 per transaction. In terms of value, about 93 percent of all interbank transactions in Indonesia are settled through the BI-RTGS, which as at end of June 2009 recorded average daily transaction activity of 39,250 by volume and Rp 174 trillion by value.

\section{BI also administers the national clearing system, $\mathrm{SKN}$-BI in terms of the powers} granted by the BI statute. The system handles the clearing of debit-pull and credit-push instruments throughout the country. In areas where BI is not represented, agents in the form of commercial banks have been appointed to carry out the clearing function on behalf of the central bank. SKN-BI was established in 2005, and handles clearing through over 100 clearing facilities established throughout the country. The debit clearing within SKN-BI involves paper based instruments including cheques and debit notes. The arrangements are localized with the clearing operator having the responsibility of ensuring that obligations are calculated correctly before they are sent to BI for settlement through the BI-RTGS system. There is no threshold imposed on debit clearing; hence cheques of a high value nature can still be issued by customers in this regard. Unlike debit clearing, the credit clearing process is non-paper based and involves the clearing of credit instructions between banks before settlement takes place. A threshold of Rp 100 million is imposed in credit clearing. Any amounts exceeding this threshold must be processed through the RTGS system. The transactions cleared through SKN-BI have maintained an upward trend over the years 2006 to 2008 in both value and volume terms. 
15. Over the last decade, BI has been involved in collaborative efforts to reform the payment system in Indonesia. The existing blueprint that provides guidance to this process is currently being revised in response to the ever changing payments environment and to set strategic direction for the critical international linkages being envisaged by BI.

\section{Main Findings}

\section{Legal Framework (CP I)}

16. The legal foundation for payment systems in Indonesia is generally sound with explicit provisions for the central bank's involvement in payment systems. A number of statutes have been enacted and these are supported by regulations and circular letters that the BI issues from time to time. The authorities should however consider enacting a specific law that governs payment systems as well as address any areas that need further strengthening and clarity. For example, in order to eliminate ambiguity and uncertainty, there is need to explicitly recognize netting as a legal process. In this regard, it should be noted that reference to the term in the circulars or rules does not translate to recognition of - netting" as a legal term.

\section{Management of Risk (CP II-III)}

17. The BI-RTGS generally functions well and is recognized as the only SIPS in Indonesia. System participants have a good understanding of the financial risks and the need to contain these in accordance with operating rules. The rules cover various aspects which include systems operation and oversight; consumer protection, system features. Participants are well informed and have a clear understanding of the risk of participation and the need to manage the same. Authorities must be commended for the -observed" rating allocated to all risk related CPs in this assessment

\section{Settlement (CPIV-VI)}

18. Over and above the clarity of BI-RTGS rules, the system design is such that once a transaction is accepted in the system, and the respective accounts debited and credited it is deemed final and cannot be revoked. This position is also supported by explicit provision in the regulations. The operating schedule is adhered to and any interruptions are communicated to the participants. The system has a queuing mechanism and participants fully understand that queued transactions are not settled and have to be discarded at the end of the day if they are not funded.

\section{Operational Reliability and Efficiency (CPVII-VIII)}

19. BI has adequate contingency plans in place to address any technical problems; a general security policy that is set by the Board is applied across applications used by the Bank. The business continuity procedures are well documented and the disaster recovery site which is manned by a small contingency of staff is tested periodically to ensure its ability to take over the primary production environment in the event of a challenge. The 40 kilometer separation between the production site and the DR site is however minimally acceptable particularly for an environment that is prone to natural disruptions. The two main systems operated by BI, (BI-RTGS and BI-Securities Settlement System) and linking external 
participants are based on legacy technologies which have been replaced by modern technology. BI has advanced plans to implement a new second generation system in 2011. In allocating the -observed" rating to CP IV, these advanced plans were taken into account and must therefore be realized within the stipulated time in order to maintain full observance of the two CPs in future.

Access and Governance (CP IX-X)

20. There is absence of clear, documented access criteria based on specific indicators. This position appears to have been influenced by the historic position taken by BI requiring all banks to be direct participants in the system. Hence any bank that is licensed has direct access to the system on application. The BI would benefit from access criteria that are based on specific indicators agreed between the Payment Systems Department and the Banking Supervision Department. While not being restrictive and stifling competition, such criteria should act as a risk management tool by ensuring that weak banks that are likely to pose systemic risk to the system are not automatically granted access. Limiting access to banks only is increasingly becoming an exception for most central banks. In considering the option of granting access to non banks, BI will need to give attention to the final settlement needs of the market, as well as clearly distinguish between the access to settlement account only and access to central bank credit and settlement account.

\section{Central Bank Responsibilities (CBRs) A-D}

\section{BIs payment systems objectives are clearly documented and publicly disclosed via} the website and communication with the National Payment System Communication

Forum. There is scope for broadening and deepening BI's communication with key stakeholders in the payment system. Such communication should incorporate the explicit pronunciation of the direction being taken at national level to achieve the objectives identified in the blueprint. The revision of the blueprint provides a good opportunity for BI to strengthen consultation with banks and other stakeholders. BI has defined its payment system oversight narrowly and focuses on overseeing only the systems it operates with an operator's perspective. Rapid developments of the financial system will likely raise the profile of a number of systems and it is important for BI to anticipate pressure on the oversight function by ensuring adequate resources both in terms of staff levels and skills. BI cooperates with other central banks in the region and also gets technical assistance from other central banks. Cooperation with domestic authorities and regulators could be improved and structured by signing formal MOUs and creating joint working groups, when appropriate. This applies to cooperation with other functions of BI (e.g. the Bank Supervision Department) and other external authorities and regulators (e.g. Bapepam, and the telecommunications regulatory authority.

Table 1 Summary Observance of the CPSIPS and Central Bank Responsibilities in Applying the CPs-ROSCs

Core Principle/Responsibility

Legal foundation
Comments

CInternational Monetary Fund. Not for Redistribution 


\begin{tabular}{|c|c|}
\hline $\begin{array}{l}\text { CP I - The system should have a well-founded legal } \\
\text { basis under all relevant jurisdictions }\end{array}$ & $\begin{array}{l}\text { The legal foundation generally provides a basis for } \\
\text { the development of payment systems in Indonesia. It } \\
\text { consists of various statutes, regulations, agreements } \\
\text { and circular letters. However, there is no explicit } \\
\text { recognition of the practice of - netting" as a legal } \\
\text { term even though it is referred to in the rules and } \\
\text { circular letters. This aspect needs to be addressed if } \\
\text { BI is to fully observe this Principle. } \\
\text {. }\end{array}$ \\
\hline \multicolumn{2}{|l|}{ Understand and management of risks } \\
\hline $\begin{array}{l}\text { CP II - The system's rules and procedures should } \\
\text { enable participants to have a clear understanding of } \\
\text { the system's impact on each of the financial risks they } \\
\text { incur through participation in it. }\end{array}$ & $\begin{array}{l}\text { System rules and procedures are clear to the } \\
\text { participants. The formation of the banking industry } \\
\text { By Laws Committee and the dialogue with BI } \\
\text { promote understanding of risks and participants' } \\
\text { obligations. The - credit push" feature of the system, } \\
\text { prefunding and intraday facility help in ensuring } \\
\text { flow of payments within the system. However, the } \\
\text { lack of a hybrid feature in the system design might } \\
\text { mean liquidity is not being optimized and can lead to } \\
\text { queue build up. }\end{array}$ \\
\hline $\begin{array}{l}\text { CP III - The system should have clearly defined } \\
\text { procedures for the management of credit risks and } \\
\text { liquidity risks, which specify the respective } \\
\text { responsibilities of the system operator and the } \\
\text { participants and which provide appropriate incentives } \\
\text { to manage and contain those risks. }\end{array}$ & $\begin{array}{l}\text { See comments under CP II above. In addition, credit } \\
\text { risk in the system is minimized by system design, } \\
\text { use of collateralized intraday credit facilities, } \\
\text { throughput guidelines and queue management } \\
\text { system. }\end{array}$ \\
\hline \multicolumn{2}{|l|}{ Settlement } \\
\hline $\begin{array}{l}\text { CP IV - The system should provide prompt final } \\
\text { settlement on the day of value, preferably during the } \\
\text { day and at a minimum at the end of the day. }\end{array}$ & $\begin{array}{l}\text { Participants understand when finality takes place and } \\
\text { system operating hours are followed as far as } \\
\text { possible. } \\
\text { However, items can be discarded from the queue at } \\
\text { the end of the day if funding capacity (cash or } \\
\text { collateral sufficient for central bank overnight repo } \\
\text { lending) is lacking. While this has implications for } \\
\text { payment system effectiveness, especially for the } \\
\text { certainty of cash settlement in the secondary market } \\
\text { for government securities, for RTGS purposes, this } \\
\text { CP is observed. }\end{array}$ \\
\hline $\begin{array}{l}\text { CP V - A system in which multilateral netting takes } \\
\text { place should, at a minimum, be capable of ensuring } \\
\text { the timely completion of daily settlements in the event } \\
\text { of an inability to settle by the participant with the } \\
\text { largest single settlement obligation }\end{array}$ & Not Applicable \\
\hline $\begin{array}{l}\text { CP VI - Assets used for settlement should preferably } \\
\text { be a claim on the central bank; where other assets are } \\
\text { used, they should carry little or no credit risk and little } \\
\text { or no liquidity risk. }\end{array}$ & $\begin{array}{l}\text { BI-RTGS settles in central bank money. A } \\
\text { collateralized intraday credit facility is in place to } \\
\text { ensure smooth flow of payments in the system. }\end{array}$ \\
\hline \multicolumn{2}{|l|}{ Operational reliability and efficiency } \\
\hline $\begin{array}{l}\text { CP VII - The system should ensure a high degree of } \\
\text { security and operational reliability and should have } \\
\text { contingency arrangements for timely completion of } \\
\text { daily processing }\end{array}$ & $\begin{array}{l}\text { The technologies supporting the current RTGS } \\
\text { application have been superseded. } \\
\text { System availability is very good although SLAs } \\
\text { could be strengthened. } \\
\text { Telecommunications support appears to be generally } \\
\text { sufficient although continuing attention is needed }\end{array}$ \\
\hline
\end{tabular}




\begin{tabular}{|c|c|}
\hline & $\begin{array}{l}\text { regarding connectivity in outlying areas. It is crucial } \\
\text { that BI migrate to the new second generation RTGS } \\
\text { (and SSSS) platform in } 2011 \text { as planned in order to } \\
\text { further strengthen reliability and security as well as } \\
\text { maintain observance of this CP in future. The } \\
\text { number and skills of technical staff need to be } \\
\text { evaluated in preparation for this migration. }\end{array}$ \\
\hline $\begin{array}{l}\text { CP VIII - The system should provide a means of } \\
\text { making payments, which is practical for its users and } \\
\text { efficient for the economy. }\end{array}$ & $\begin{array}{l}\text { While the current system design generally supports } \\
\text { the financial efficiency needs of the payment system, } \\
\text { the second generation hybrid design will improve it. } \\
\text { In addition, there are opportunities, including } \\
\text { benchmarking, to ensure that cost efficiency meets } \\
\text { needs and expectations. }\end{array}$ \\
\hline \multicolumn{2}{|l|}{ Access and governance } \\
\hline $\begin{array}{l}\text { CP IX - The system should have objective and } \\
\text { publicly disclosed criteria for participation, which } \\
\text { permit fair and open access. }\end{array}$ & $\begin{array}{l}\text { Clear, explicit, well documented access criteria are } \\
\text { needed. The criteria should take into account the } \\
\text { BI's broader plans as envisaged in the new RTGS } \\
\text { and SSSS systems and the final settlement needs of } \\
\text { the financial markets. }\end{array}$ \\
\hline $\begin{array}{l}\text { CP X - The system's governance arrangements } \\
\text { should be effective, accountable and transparent. }\end{array}$ & $\begin{array}{l}\text { Separation of duties especially between operations } \\
\text { and oversight, and collaborative engagement with } \\
\text { RTGS stakeholders provide a good governance } \\
\text { foundation. Going forward there may be } \\
\text { opportunities to strengthen further the oversight of } \\
\text { securities settlement and the proactive role of BI as } \\
\text { an overseer. }\end{array}$ \\
\hline \multicolumn{2}{|l|}{ Central bank responsibilities } \\
\hline $\begin{array}{l}\text { Responsibility A - The central bank should define } \\
\text { clearly its payment system objectives and should } \\
\text { disclose publicly its role and major policies with } \\
\text { respect to systemically important payment systems. }\end{array}$ & $\begin{array}{l}\text { The development of objectives and plans could } \\
\text { benefit from the addition of some - top down" } \\
\text { consultation as well as from a payment system } \\
\text { research agenda. }\end{array}$ \\
\hline $\begin{array}{l}\text { Responsibility B - The central bank should ensure } \\
\text { that the systems it operates comply with the core } \\
\text { principles }\end{array}$ & $\begin{array}{l}\text { The BI oversight function is carried out on the } \\
\text { RTGS system, which BI recognizes as the only SIPS } \\
\text { in Indonesia currently. } \\
\text { Placement of responsibility for BI-SSSS oversight is } \\
\text { not clear, although there are plans to have the BI- } \\
\text { SSSS under the ambit of the Payment Systems Unit. } \\
\text { BI has subjected itself to four self assessments since } \\
\text { 2005; two of these were peer reviewed. }\end{array}$ \\
\hline $\begin{array}{l}\text { Responsibility C - The central bank should oversee } \\
\text { observance with the core principles by systems it does } \\
\text { not operate and it should have the ability to carry out } \\
\text { this oversight. }\end{array}$ & $\begin{array}{l}\text { Oversight is carried out on the BI RTGS. } \\
\text { However, there is no formal oversight on other } \\
\text { settlement systems, with the potential of being } \\
\text { systemically important or of a system-wide } \\
\text { importance. }\end{array}$ \\
\hline $\begin{array}{l}\text { Responsibility D - The central bank, in promoting } \\
\text { payment system safety and efficiency through the core } \\
\text { principles, should cooperate with other central banks } \\
\text { and with any other relevant domestic or foreign } \\
\text { authorities. }\end{array}$ & $\begin{array}{l}\text { BI cooperates with other central banks in the region } \\
\text { and is currently getting technical assistance from the } \\
\text { Bundesbank. } \\
\text { BI follows international practices in payment } \\
\text { systems and liaises with international bodies on } \\
\text { payment systems. } \\
\text { The prospective link with the HK dollar clearing } \\
\text { system is a useful case study of cooperation with the } \\
\text { community of concerned central banks under the } \\
\text { CPSS cooperative oversight framework. Scope }\end{array}$ \\
\hline
\end{tabular}


remains for increasing domestic cooperation with other regulatory authorities.

CInternational Monetary Fund. Not for Redistribution 


\section{Recommended Actions and Authorities Response}

Table 2 Recommended Actions to Improve Observance of the CPSIPS and Central Bank Responsibilities in Applying the CPs-BI-RTGS

\begin{tabular}{|l|l|}
\hline \multicolumn{1}{|c|}{ Reference principle } & \multicolumn{1}{c|}{ Recommended action } \\
\hline $\begin{array}{l}\text { Legal foundation } \\
\text { CP I }\end{array}$ & $\begin{array}{l}\text { Consider enacting specific law to govern payment systems } \\
\text { operations and taking steps to explicitly recognize netting as a } \\
\text { legal process. }\end{array}$ \\
\hline $\begin{array}{l}\text { Criteria for participation } \\
C P I X\end{array}$ & $\begin{array}{l}\text { Consider introducing clear documented access criteria based } \\
\text { on specific indicators, for both direct and indirect participants. }\end{array}$ \\
\hline $\begin{array}{l}\text { Governance of the payment system } \\
C P X\end{array}$ & $\begin{array}{l}\text { Consider setting up BI-RTGS User Group to encourage } \\
\text { dialogue on system specific issues. } \\
\text { Extend oversight activities to RTGS participants and broaden } \\
\text { communications with stakeholders. }\end{array}$ \\
\hline $\begin{array}{l}\text { Central Bank Responsibilities in applying the CPs } \\
\text { Responsibilities } B, C, D\end{array}$ & $\begin{array}{l}\text { Consider measures to meet full compliance for all CPs. } \\
\text { Widen scope of oversight and strengthen activities through } \\
\text { formal arrangements. } \\
\text { Improve and structure cooperation with other domestic } \\
\text { authorities and regulators by signing formal MOUs and } \\
\text { creating joint working groups, where appropriate. This applies } \\
\text { to cooperation with other functions of BI (e.g. the Bank } \\
\text { Supervision Department) and other external authorities and } \\
\text { regulators (e.g. Bapepam, and the telecommunications } \\
\text { regulatory authority). }\end{array}$ \\
\hline
\end{tabular}

\section{Authorities' response}

22. The recommended action on CP I (Legal Foundation) was for authorities to consider enacting a specific law to govern payment systems operations as well as take steps to explicitly recognize netting as a legal process. BI noted that currently there are regulations in existence governing netting settlement e.g. in BI regulations on national clearing system. While agreeing that it is necessary to have an Act or statute that governs payment and settlement systems, (including netting) BI pointed out that the process of enacting a statute is time consuming and involves many parties.

23. The recommended action on CP IX (Access and Governance) was for authorities to consider introducing clear, documented access criteria based on specific indicators, for both direct and indirect participants. BI agreed with this recommendation and advised that access criteria are being reviewed to give clear and explicit indicators.

24. In response to the recommendation under CP X to set up a BI-RTGS User Group to encourage dialogue on system specific issues, extend oversight activities to RTGS participants as well as broaden communications with stakeholders, BI advised that the operator of BI-RTGS already conducts on site examination of several members as a tool for 
oversight. BI noted that the oversight function needs to extend activities to operational activities of securities settlement system.

25. With regard to central bank responsibilities (CBRs) in applying the core principles (CBR B, C and D), the recommended actions were for BI to consider employing measures that would help in achieving full observance of all CPs; widening the scope of oversight and strengthening activities through formal arrangements; and lastly, improving the structure and cooperation with other domestic authorities and regulators by signing formal MOUs and creating joint working groups, where appropriate. This applies to cooperation with other functions of BI (e.g. the Bank Supervision Department) and other external authorities and regulators (e.g. Bapepam, and the telecommunications regulatory authority).

26. BI fully agrees with taking appropriate measures to ensure full observance of all CPs. The oversight of the BI-SSSS will commence in 2010 in accordance with the consolidation of BI-RTGS and BI-SSSS under the Payment Systems Directorate. BI further advised that coordination with Banking Supervision Department has been conducted in the form of information exchanges and joint teams in on-site examination. Cooperation with other authorities (Bapepam-LK and Ministry of Information and Communication) will be discussed and followed up. 


\section{Detailed ASSESSMent}

Table 3 Summary observance of CPSS Core Principles and Central Bank Responsibilities in applying the CPs-Detailed Assessments

\begin{tabular}{|c|c|c|}
\hline Core Principle/Responsibility & Grading & Comments \\
\hline \multicolumn{3}{|l|}{ Legal foundation } \\
\hline $\begin{array}{l}\text { CP I - The system should have a well- } \\
\text { founded legal basis under all relevant } \\
\text { jurisdictions }\end{array}$ & BO & $\begin{array}{l}\text { The legal framework is supported by statutes, } \\
\text { regulations, agreements and circular letters } \\
\text { which provide a basis for BIs involvement in } \\
\text { payment systems and for taking the leading } \\
\text { role in modernization efforts. } \\
\text { There is no explicit recognition of the } \\
\text { practice of - netting" in the statutes. }\end{array}$ \\
\hline \multicolumn{3}{|l|}{ Understand and management of risks } \\
\hline $\begin{array}{l}\text { CP II - The system's rules and procedures } \\
\text { should enable participants to have a clear } \\
\text { understanding of the system's impact on each } \\
\text { of the financial risks they incur through } \\
\text { participation in it. }\end{array}$ & $\mathbf{O}$ & $\begin{array}{l}\text { System rules and procedures are clear to the } \\
\text { participants. The formation of the industry By } \\
\text { Laws Committee and the dialogue with BI } \\
\text { promote understanding of risks and } \\
\text { participants' obligations. The -credit push" } \\
\text { feature of the system, prefunding and } \\
\text { intraday facility help in ensuring flow of } \\
\text { payments within the system. However, the } \\
\text { lack of a hybrid feature in the system design } \\
\text { might mean liquidity is not being optimized } \\
\text { and can lead to queue build up. }\end{array}$ \\
\hline $\begin{array}{l}\text { CP III - The system should have clearly } \\
\text { defined procedures for the management of } \\
\text { credit risks and liquidity risks, which specify } \\
\text { the respective responsibilities of the system } \\
\text { operator and the participants and which } \\
\text { provide appropriate incentives to manage and } \\
\text { contain those risks. }\end{array}$ & $\mathbf{O}$ & See comments under CP II above. \\
\hline \multicolumn{3}{|l|}{ Settlement } \\
\hline $\begin{array}{l}\text { CP IV - The system should provide prompt } \\
\text { final settlement on the day of value, } \\
\text { preferably during the day and at a minimum at } \\
\text { the end of the day. }\end{array}$ & $\mathbf{O}$ & $\begin{array}{l}\text { Participants understand when finality takes } \\
\text { place. System operating hours are followed. } \\
\text { However, items can be discarded from the } \\
\text { queue at the end of the day if funding } \\
\text { capacity (cash or collateral sufficient for } \\
\text { central bank overnight repo lending) is } \\
\text { lacking. This has implications for payment } \\
\text { system effectiveness, especially for the } \\
\text { certainty of cash settlement in the secondary } \\
\text { market for government securities. }\end{array}$ \\
\hline $\begin{array}{l}\text { CP V-A system in which multilateral netting } \\
\text { takes place should, at a minimum, be capable } \\
\text { of ensuring the timely completion of daily } \\
\text { settlements in the event of an inability to } \\
\text { settle by the participant with the largest single } \\
\text { settlement obligation }\end{array}$ & $\mathbf{N} / \mathbf{A}$ & Not Applicable \\
\hline
\end{tabular}




\begin{tabular}{|c|c|c|}
\hline $\begin{array}{l}\text { CP VI - Assets used for settlement should } \\
\text { preferably be a claim on the central bank; } \\
\text { where other assets are used, they should carry } \\
\text { little or no credit risk and little or no liquidity } \\
\text { risk. }\end{array}$ & $\mathbf{O}$ & $\begin{array}{l}\text { BI-RTGS settles in central bank money. A } \\
\text { collateralized intraday credit facility is in } \\
\text { place to smoothen the flow of payments in } \\
\text { the system. }\end{array}$ \\
\hline \multicolumn{3}{|l|}{ Operational reliability and efficiency } \\
\hline $\begin{array}{l}\text { CP VII - The system should ensure a high } \\
\text { degree of security and operational reliability } \\
\text { and should have contingency arrangements } \\
\text { for timely completion of daily processing }\end{array}$ & $\mathbf{O}$ & $\begin{array}{l}\text { The technologies supporting the current } \\
\text { RTGS application have been superseded. } \\
\text { System availability is very good although } \\
\text { SLAs could be strengthened. } \\
\text { Telecommunications support appears to be } \\
\text { generally sufficient although continuing } \\
\text { attention is needed regarding connectivity in } \\
\text { outlying areas. It is crucial that BI migrate to } \\
\text { the new second generation RTGS (and SSSS) } \\
\text { platform in a timely manner to further } \\
\text { strengthen reliability and security. The } \\
\text { number and skills of technical staff need to be } \\
\text { evaluated in preparation for this migration. }\end{array}$ \\
\hline $\begin{array}{l}\text { CP VIII - The system should provide a means } \\
\text { of making payments, which is practical for its } \\
\text { users and efficient for the economy. }\end{array}$ & $\mathbf{O}$ & $\begin{array}{l}\text { While the current system design generally } \\
\text { supports the financial efficiency needs of the } \\
\text { payment system, the second generation } \\
\text { hybrid design will improve it. In addition, } \\
\text { there are opportunities, including } \\
\text { benchmarking, to ensure that cost efficiency } \\
\text { meets needs and expectations. }\end{array}$ \\
\hline \multicolumn{3}{|l|}{ Access and governance } \\
\hline $\begin{array}{l}\text { CP IX - The system should have objective } \\
\text { and publicly disclosed criteria for } \\
\text { participation, which permit fair and open } \\
\text { access. }\end{array}$ & BO & $\begin{array}{l}\text { Clear, explicit, well documented access } \\
\text { criteria are needed. The criteria should take } \\
\text { into account the BI's broader plans as } \\
\text { envisaged in the new RTGS and SSSS } \\
\text { systems and the final settlement needs of the } \\
\text { financial markets. }\end{array}$ \\
\hline $\begin{array}{l}\text { CP X - The system's governance } \\
\text { arrangements should be effective, accountable } \\
\text { and transparent. }\end{array}$ & BO & $\begin{array}{l}\text { Separation of duties especially between } \\
\text { operations and oversight, and collaborative } \\
\text { engagement with RTGS stakeholders provide } \\
\text { a good governance foundation. Going } \\
\text { forward there may be opportunities to } \\
\text { strengthen further the oversight of securities } \\
\text { settlement and the proactive role of BI as an } \\
\text { overseer. }\end{array}$ \\
\hline \multicolumn{3}{|l|}{ Central bank responsibilities } \\
\hline $\begin{array}{l}\text { Responsibility A - The central bank should } \\
\text { define clearly its payment system objectives } \\
\text { and should disclose publicly its role and major } \\
\text { policies with respect to systemically important } \\
\text { payment systems. }\end{array}$ & $\mathbf{O}$ & $\begin{array}{l}\text { The development of objectives and plans } \\
\text { could benefit from the addition of some - top } \\
\text { down" consultation as well as from a } \\
\text { payment system research agenda. }\end{array}$ \\
\hline $\begin{array}{l}\text { Responsibility B - The central bank should } \\
\text { ensure that the systems it operates comply } \\
\text { with the core principles }\end{array}$ & BO & $\begin{array}{l}\text { The BI oversight function is carried out on } \\
\text { the RTGS system, which BI recognizes as the } \\
\text { only SIPS in Indonesia currently. } \\
\text { Placement of responsibility for BI-SSSS } \\
\text { oversight could be clarified. } \\
\text { BI has subjected itself to four self } \\
\text { assessments since 2005; two of these were }\end{array}$ \\
\hline
\end{tabular}




\begin{tabular}{|l|c|l|}
\hline & & peer reviewed. \\
\hline $\begin{array}{l}\text { Responsibility C - The central bank should } \\
\text { oversee observance with the core principles } \\
\text { by systems it does not operate and it should } \\
\text { have the ability to carry out this oversight. }\end{array}$ & PO & $\begin{array}{l}\text { Oversight is carried out on the BI RTGS. } \\
\text { However, there is no formal oversight on } \\
\text { other settlement systems, with the potential of } \\
\text { being systemically important or of a system- } \\
\text { wide importance. }\end{array}$ \\
\hline $\begin{array}{l}\text { Responsibility D - The central bank, in } \\
\text { promoting payment system safety and } \\
\text { efficiency through the core principles, should } \\
\text { cooperate with other central banks and with } \\
\text { any other relevant domestic or foreign } \\
\text { authorities. }\end{array}$ & BO & $\begin{array}{l}\text { BI cooperates with other central banks in the } \\
\text { region and is currently getting technical } \\
\text { assistance from the Bundesbank. } \\
\text { BI follows international practices in payment } \\
\text { systems and liaises with international bodies } \\
\text { on payment systems. } \\
\text { The prospective link with the HK dollar } \\
\text { clearing system is a useful case study of } \\
\text { cooperation with the community of } \\
\text { concerned central banks under the CPSS } \\
\text { cooperative oversight framework. Scope } \\
\text { remains for increasing domestic cooperation } \\
\text { with other regulatory authorities. }\end{array}$ \\
\hline $\begin{array}{l}\text { Legend: Observed (O) 7-, Broadly observed (BO) 5-, Partly observed (PO) 1 - , Not observed (NO) 0 - } \\
\text { Not applicable (N/A) 1- }\end{array}$ & \multicolumn{2}{|l}{} \\
\hline
\end{tabular}


Table 4 Detailed Assessment of BI-RTGS Observance of the CPSS CPSIPS and the BI Responsibilities in Applying the CPSIPS

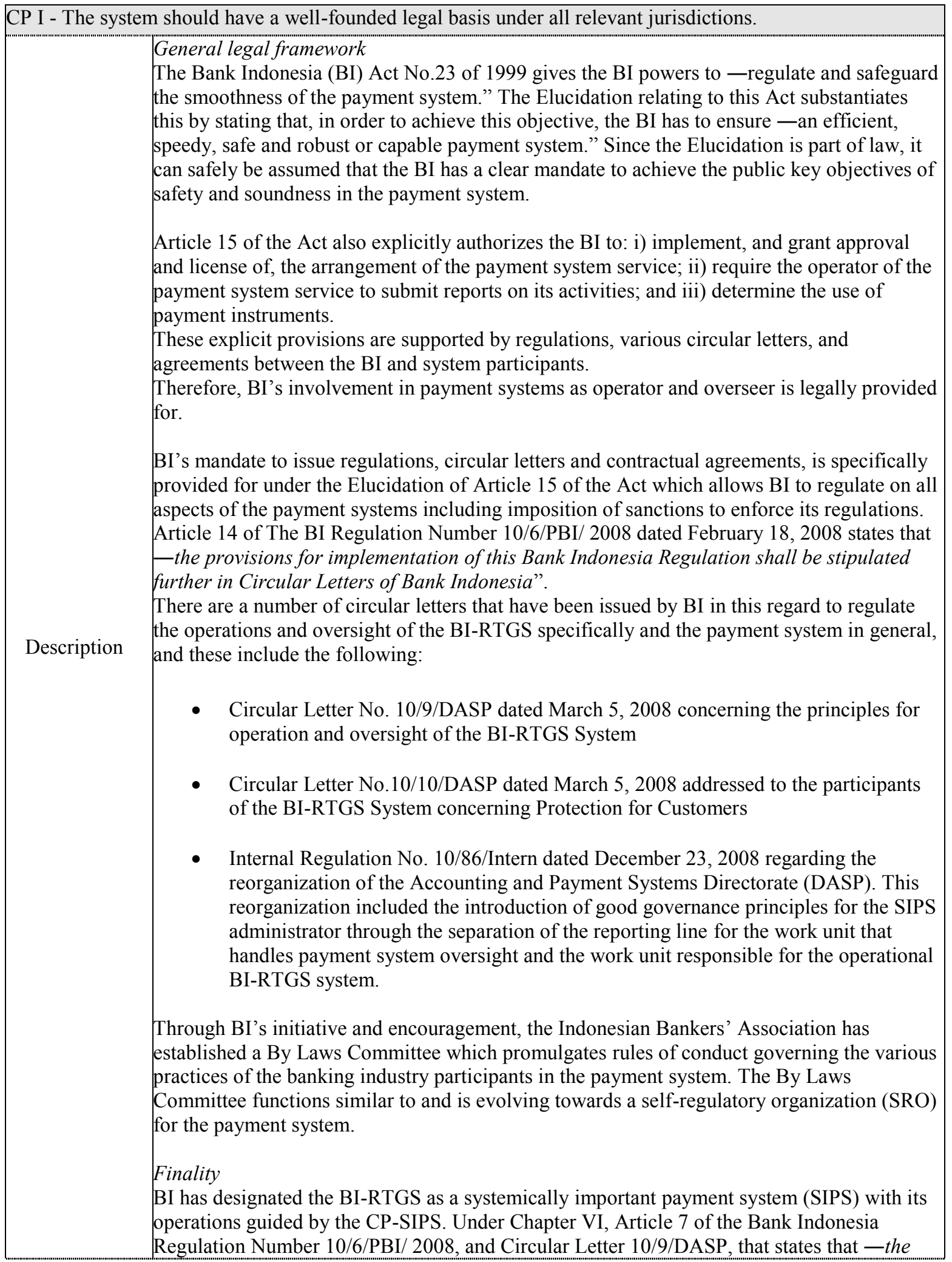




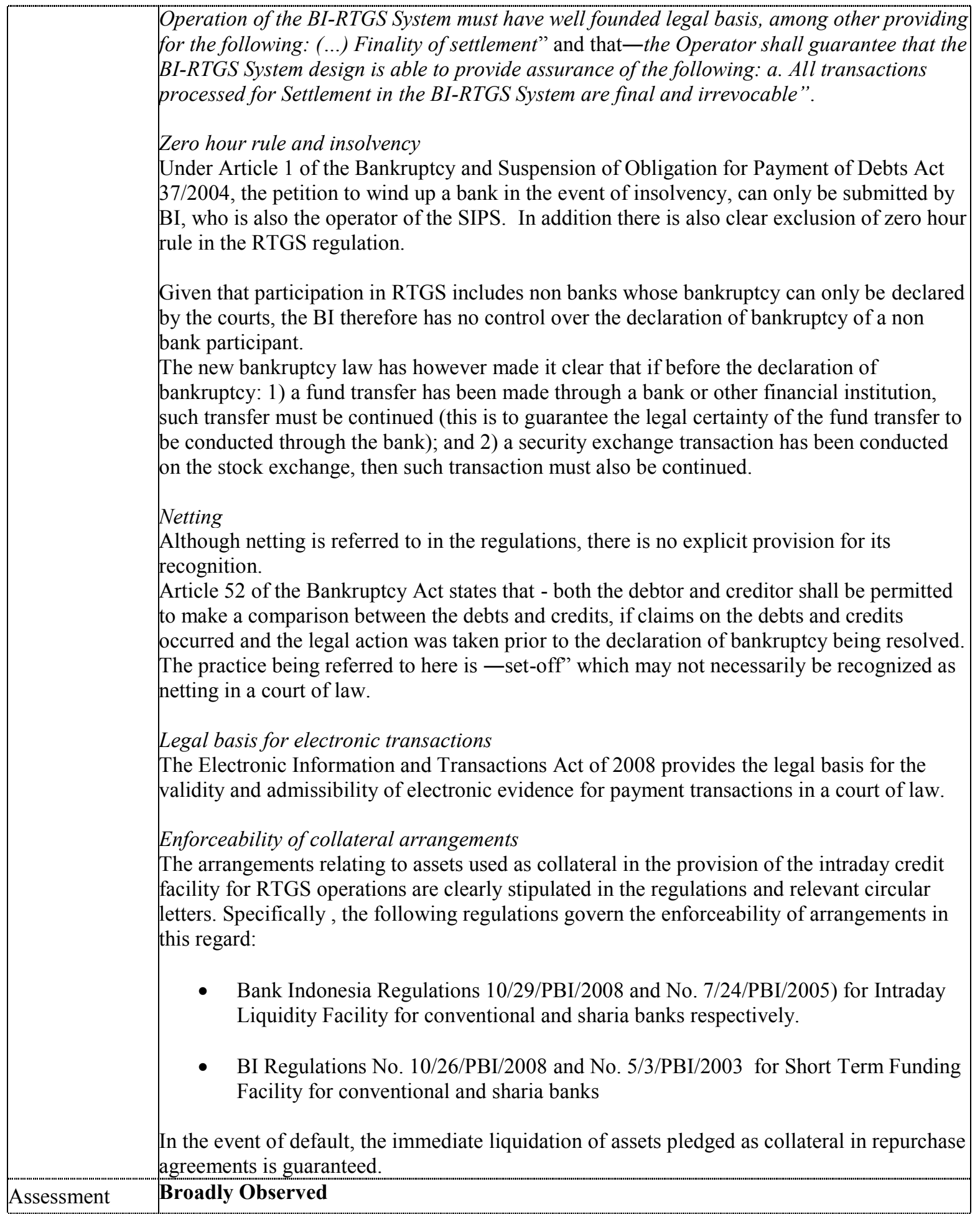




\begin{tabular}{|c|c|}
\hline Comments & $\begin{array}{l}\text { The powers of the central bank related to its operating and oversight responsibilities are, as a } \\
\text { result of various amendments made over time, scattered throughout pieces of legislation. It } \\
\text { would be useful to enact a specific law that governs the national payment system that brings } \\
\text { all of these powers together in a single place. } \\
\text { The bilateral agreement between BI as RTGS operator (and SSSS operator) and the system } \\
\text { participants appears somewhat duplicative with the requirements contained in the regulations } \\
\text { and circular letters. Also, the bi-lateral agreement sometimes refers to - participants" not } \\
\text { specifically to the bank signatory, as if it were a general circular letter as opposed to a bi- } \\
\text { lateral contract. In the interest of clarity, it may be useful to compress the length of the bi- } \\
\text { lateral agreement to the minimum needed to formally accept banks as system participants. } \\
\text { In order to eliminate ambiguity and uncertainty, there is need to explicitly recognize netting } \\
\text { as a legal process. Set-off may not be recognized as netting, depending on the circumstances. }\end{array}$ \\
\hline \multicolumn{2}{|c|}{$\begin{array}{l}\text { CP II - The system's rules and procedures should enable participants to have a clear understanding of the } \\
\text { system's impact on each of the financial risks they incur through participation in it. }\end{array}$} \\
\hline Description & 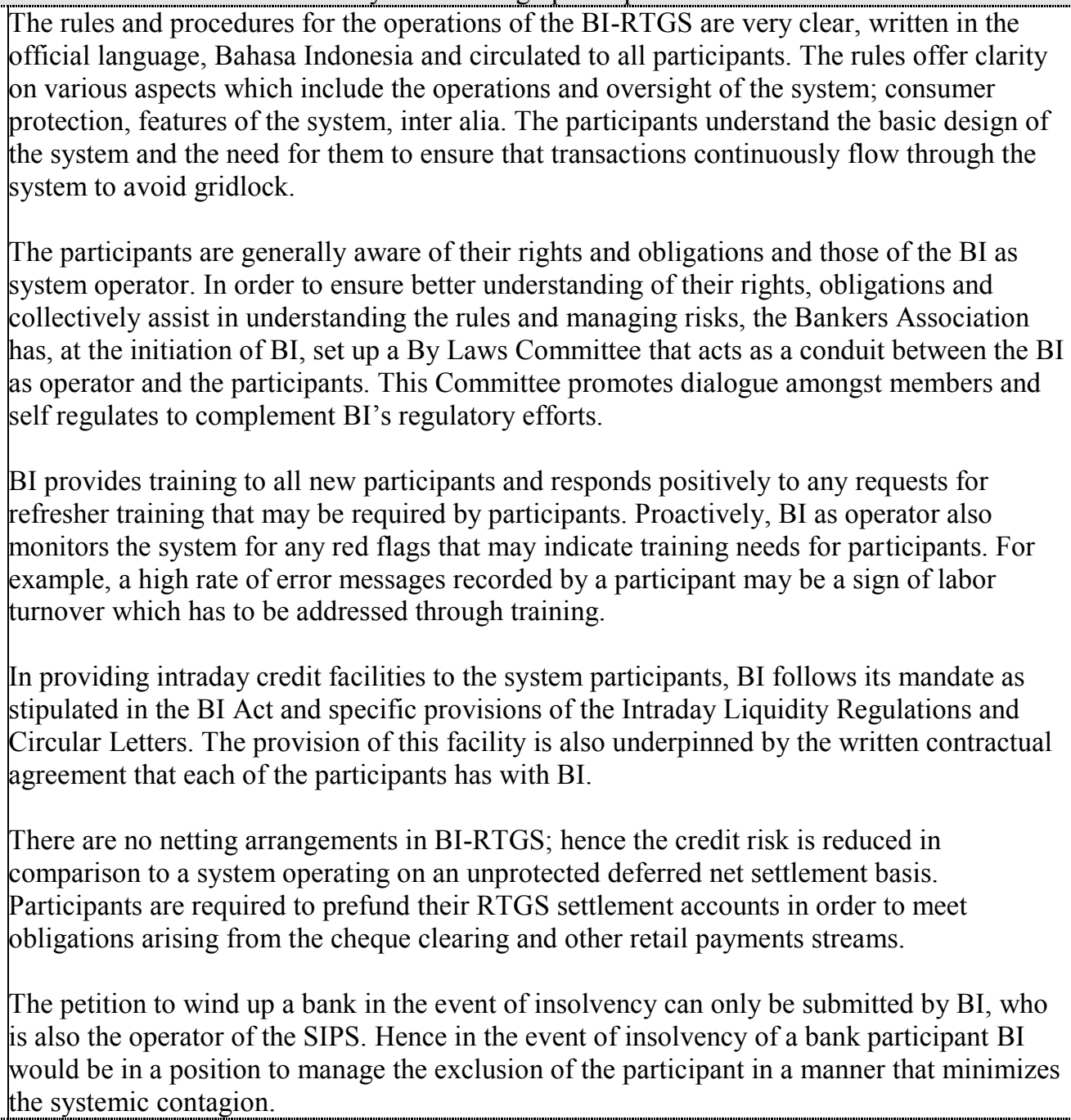 \\
\hline Assessment & Observed \\
\hline Comments & \\
\hline
\end{tabular}




\begin{tabular}{|c|c|}
\hline \multicolumn{2}{|c|}{ provide appropriate incentives to manage and contain those risks. } \\
\hline Description & 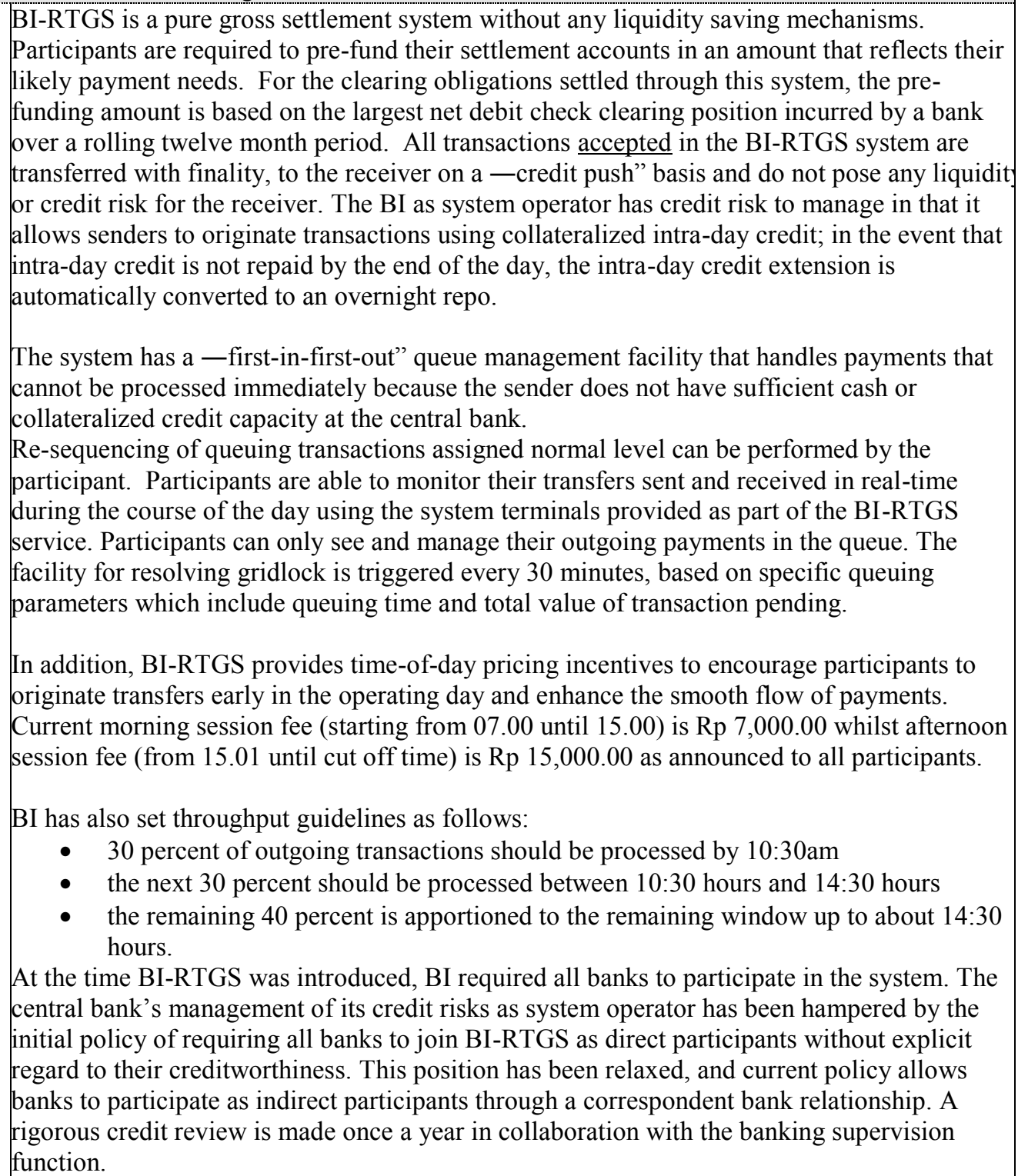 \\
\hline Asses: & Observed \\
\hline Comments & $\begin{array}{l}\text { BI still faces the difficult-announcement effect" problem whereby a bank's reputation in the } \\
\text { market is damaged as a consequence of a decision by the central bank to exclude it from the } \\
\text { RTGS as a result of creditworthiness concerns. It would be desirable for BI to adopt a more } \\
\text { intensive and on-going credit review of the participants in collaboration with the banking } \\
\text { supervision function, with the goal of anticipating participant credit risk problems. Further, } \\
\text { the new policy should provide a policy framework for dealing with banks whose } \\
\text { creditworthiness deteriorates, in a manner that takes account of the announcement effects and } \\
\text { consequence impact on the effective functioning of the financial system; this policy should } \\
\text { also be developed in close cooperation with the banking supervision function. }\end{array}$ \\
\hline \multicolumn{2}{|c|}{$\begin{array}{l}\text { CP IV - The system should provide prompt final settlement on the day of value, preferably during the day and } \\
\text { at a minimum at the end of the day. }\end{array}$} \\
\hline Description & $\begin{array}{l}\text { BI-RTGS provides final settlement in real-time. Extensions to the regular operating hours are } \\
\text { a rarity. } \\
\text { The rules are clear regarding the acceptance of payments into the RTGS processing stream } \\
\text { and about the point at which finality occurs - when the participants' accounts held at the }\end{array}$ \\
\hline
\end{tabular}




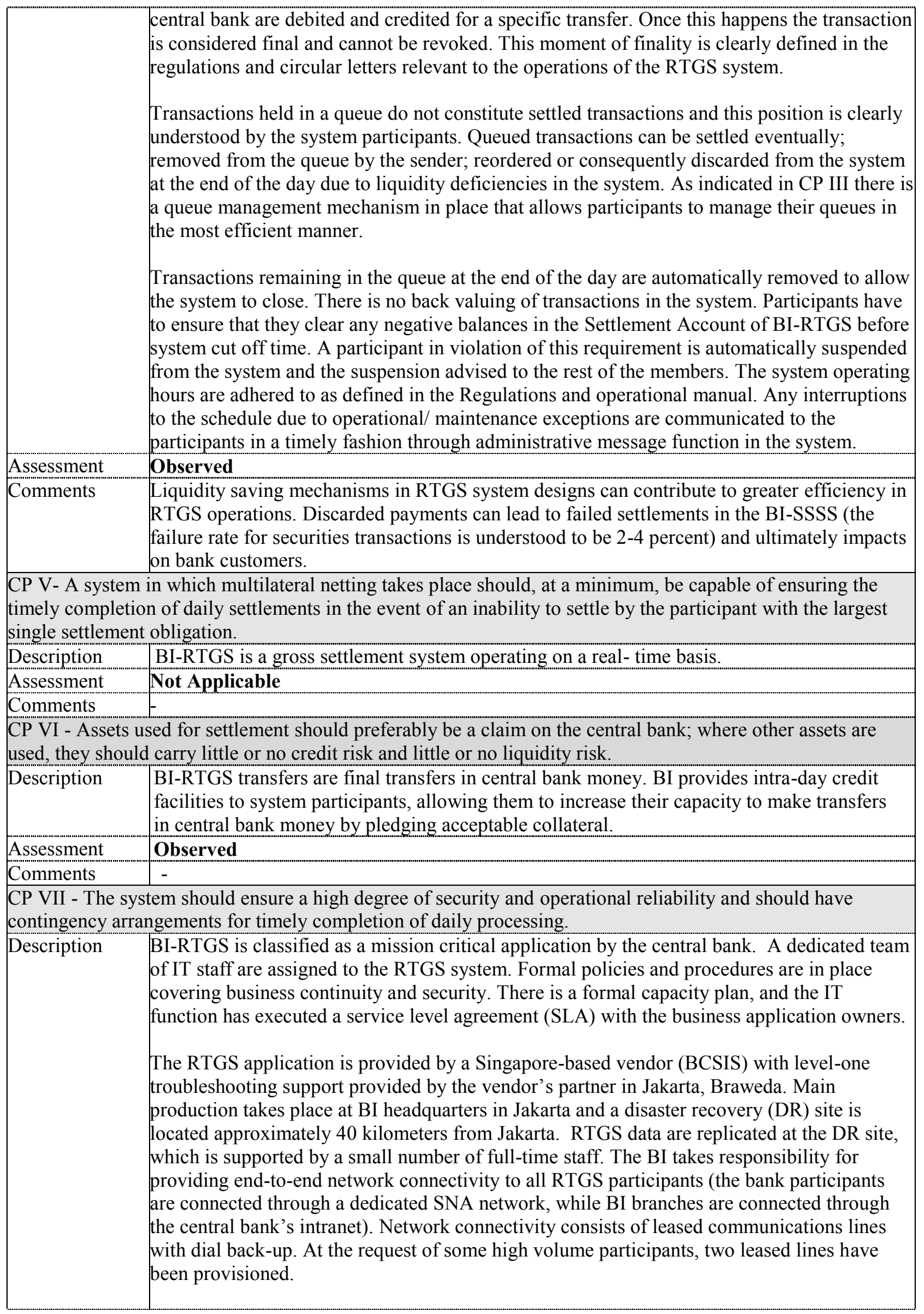




\begin{tabular}{|c|c|}
\hline & 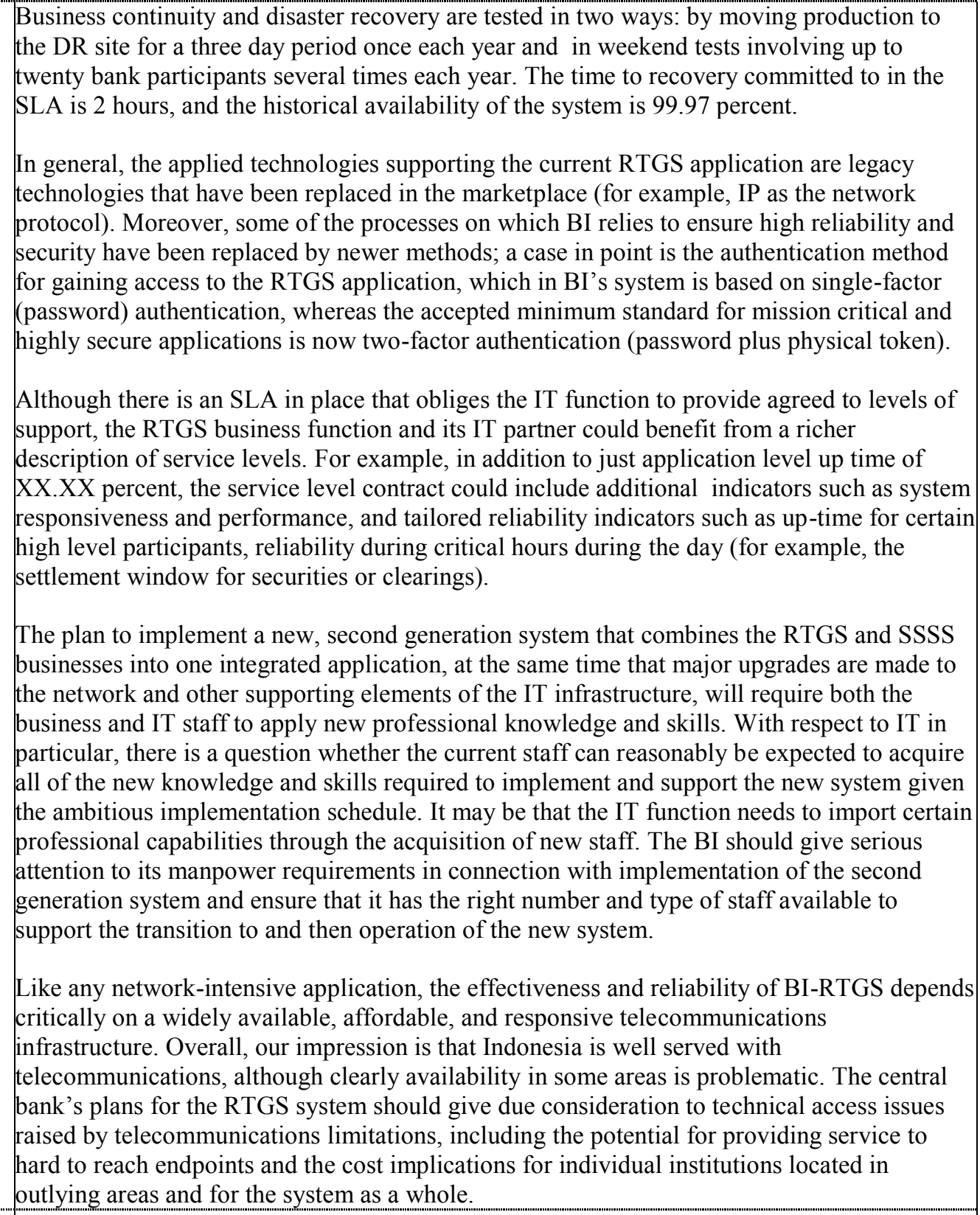 \\
\hline Assessment & Observed \\
\hline Comments & $\begin{array}{l}\text { The general reliance on legacy technologies would be a cause for concern were it not for the } \\
\text { BI's plans to implement a new, second generation RTGS in } 2011 \text {. It is critical that the new } \\
\text { application be implemented within the planned timeframe so that BI-RTGS reliability and } \\
\text { security are strengthened. } \\
\text { The } 40 \text { kilometer separation between BI and the DR site is minimally acceptable especially } \\
\text { in an environment where there is potential for geographically widespread disruption. Our } \\
\text { conversations with BI staff indicate that serious consideration is being given to locating a } \\
\text { new DR site at greater distance from the BI. We agree with and encourage serious } \\
\text { consideration of more geographically disparate production and back-up processing for BI- } \\
\text { RTGS. }\end{array}$ \\
\hline
\end{tabular}




\begin{tabular}{|c|c|}
\hline Desc & 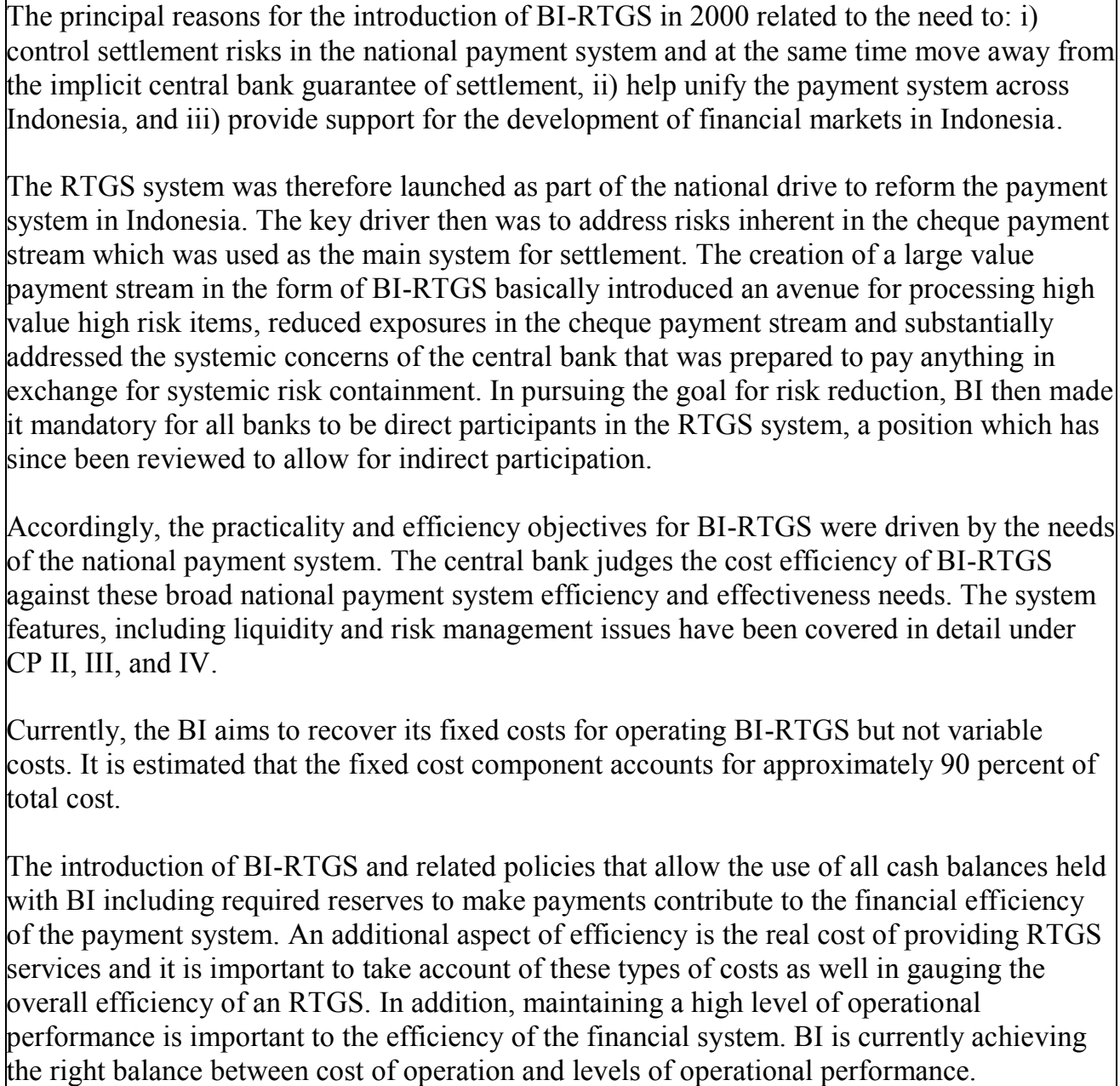 \\
\hline Assessment & Observed \\
\hline \multicolumn{2}{|c|}{$\begin{array}{l}\text { CP IX - The system should have objective and publicly disclosed criteria for participation, which permit fair } \\
\text { and open access. }\end{array}$} \\
\hline Description & $\begin{array}{l}\text { It would appear that explicit, documented criteria (based on indicators such as risk, capital } \\
\text { ratios or other) for gaining access to BI-RTGS do not exist. Commercial banks are eligible } \\
\text { for settlement accounts and intra-day credit. Nonbanks are eligible to hold settlement } \\
\text { accounts only, as a credit risk management measure. Access is either direct or indirect } \\
\text { through correspondent banks. Participants can be suspended for violations or if there is a } \\
\text { change in their creditworthiness. } \\
\text { The Regulation outlines the following as conditions that a prospective direct and indirect } \\
\text { participant must fulfill: } \\
\text { - Hold a demand deposit account at BI } \\
\text { - Provide hardware for RTGS system } \\
\text { - Sign an agreement with BI-RTGS operator } \\
\text { - For non - banks eligibility will also be based on assessment conducted by the } \\
\text { operator } \\
\text { Clearly the above are stipulations within the Regulations which participants have to comply } \\
\text { with. } \\
\text { Limiting RTGS access solely to commercial banks is increasingly becoming an exception }\end{array}$ \\
\hline
\end{tabular}




\begin{tabular}{|c|c|}
\hline & $\begin{array}{l}\text { among central banks. Providing access to a central bank account, funds transfer and other } \\
\text { services to nonbank financial institutions is consistent with national policies intended to } \\
\text { strengthen the financial markets. Also, providing access to specialized risk management } \\
\text { organizations through which settlement in important markets that give rise to large } \\
\text { transactions, including the securities and derivatives markets, can contribute to the stability } \\
\text { of the financial system. At this stage in the evolution of Indonesia's financial markets, it is } \\
\text { desirable that the central bank analyze the implications of broader access to central bank } \\
\text { services, including RTGS for the effective and safe functioning of the financial system. This } \\
\text { analysis would appropriately consider whether access should include accounts only or } \\
\text { accounts and central bank credit, and give particular attention to the final settlement needs of } \\
\text { the financial markets through the settlement and risk management organizations on which } \\
\text { those markets rely. }\end{array}$ \\
\hline Asses & Broadly Observed \\
\hline Comments & $\begin{array}{l}\text { Clear, documented access criteria based on specific indicators should be introduced in order } \\
\text { to fully observe this principle. } \\
\text { The criteria should distinguish the type of access that BI provides, and the factors that make } \\
\text { an organization eligible. The types of access that should be distinguished are for participants } \\
\text { with settlement accounts only, or those with settlement accounts and access to central bank } \\
\text { credit. These criteria should be consistently and fairly applied and should include detailed } \\
\text { provisions for the exclusion of participants. }\end{array}$ \\
\hline \multicolumn{2}{|c|}{ CP X - The system's governance arrangements should be effective, accountable and transparent. } \\
\hline Description & $\begin{array}{l}\text { BI-RTGS is owned and operated by the central bank through the Payment Systems Unit of } \\
\text { the DASP Directorate. DASP Directorate is responsible for decisions that affect the day to } \\
\text { day operations, including customer support services. By virtue of the fact that DASP is a } \\
\text { Directorate within BI, it is bound by BI's statutory provisions, and any procedures governing } \\
\text { the operations of the RTGS system therefore, have to be in line with the broader policies of } \\
\text { BI as formulated by the Board of Governors. } \\
\text { There is a clear separation of duties between the RTGS operations function and the payment } \\
\text { system oversight function under the DAPS Directorate. BI is also a participant in the system } \\
\text { through its various operating departments and, as such, is required to follow operating rules } \\
\text { and circular letters analogous to those followed by private sector participants. } \\
\text { Like other functional units within BI, the system's operations are subjected to internal audit } \\
\text { every year. } \\
\text { There is transparency in the administration of the system. Documentation pertaining to the } \\
\text { operations of the system is readily available and posted on the website of BI. } \\
\text { The BI oversight function concentrates its attention on the BI-RTGS operator but not beyond } \\
\text { the operator to the participants in the system. While the operator currently does not formally } \\
\text { oversee the participants, it is important that large RTGS participants in particular do not fall } \\
\text { outside the ambit of central bank oversight, and the BI oversight function should assess the } \\
\text { need for a more formal delineation of responsibilities. } \\
\text { There appears to be scope for bolstering communications with payment system participants, } \\
\text { key infrastructure providers, and financial regulators. This is particularly the case as BI } \\
\text { moves toward major changes in BI-RTGS such as the second generation system scheduled } \\
\text { for implementation in } 2011 \text {. }\end{array}$ \\
\hline Assessment & Broadly Observed \\
\hline Comments & $\begin{array}{l}\text { Our sense is that consultation with the industry has to date focused primarily on technical } \\
\text { change. It is equally if not more important that the industry be engaged on changes to } \\
\text { business functions as well. } \\
\text { In order to fully observe this principle, oversight of the BI-RTGS should be extended to }\end{array}$ \\
\hline
\end{tabular}




\begin{tabular}{|c|c|}
\hline & $\begin{array}{l}\text { participants and communication with stakeholders broadened and deepened. The revision of } \\
\text { the blueprint provides a good opportunity for enhanced communication. } \\
\text { It may be prudent establish a specific BI-RTGS User Group as a means of encouraging } \\
\text { dialogue amongst users on specific user issues. Membership of this Group would be confined } \\
\text { to business and technical operatives. }\end{array}$ \\
\hline & Central Bank Responsibilities in applying the CPSIPS \\
\hline & $\begin{array}{l}\text { The central bank should define clearly its payment system objectives and should } \\
\text { I major policies with respect to systemically important payment systems. }\end{array}$ \\
\hline Description & $\begin{array}{l}\text { The Bank Indonesia (BI) Act No.23 of } 1999 \text { gives the BI powers to-regulate and safeguard } \\
\text { the smoothness of the payment system." The Elucidation relating to this Act further requires } \\
\text { BI to ensure-an efficient, speedy, safe and robust or capable payment system". Drawing } \\
\text { from this mandate, BI has clearly defined its objectives and publicly disclosed its role and } \\
\text { major policies in SIPS. This disclosure is evidenced by the relevant regulations, rules, } \\
\text { circular letters that have been issued by BI and made available to the public through the } \\
\text { website. } \\
\text { BI created a payment system blueprint in } 1995 \text { and revised it in 2004. This and other } \\
\text { information on the payment system is also publicly available on the web. Consultative } \\
\text { mechanisms are in place with major financial sector stakeholders. } \\
\text { Central bank activities related to the payment system often include a research agenda and } \\
\text { sponsorship of conferences and symposia on payment system issues. The type of research } \\
\text { agenda is often supported by the central bank's research economists. }\end{array}$ \\
\hline Assessment & Observed \\
\hline Comi & $\begin{array}{l}\text { BI's approach to leading change in the payment system appears to be heavily a-bottoms up" } \\
\text { engagement with the financial industry and with the industry itself to creating the momentum } \\
\text { for change. Discussions with banking industry representatives suggest that BI staff regularly } \\
\text { serve on the working groups of the By Laws Committee and that BI lodges providing ideas } \\
\text { regarding improvements. However, it may be desirable for BI to consider whether a more } \\
\text { proactive oversight role is desirable when pressing changes are identified, and whether senior } \\
\text { level engagement with financial industry leaders should become a regular part of the } \\
\text { communications program. } \\
\text { BI may wish to consider the benefits of investing in payment system research in order to } \\
\text { raise public awareness of the importance of payment system development, and as a means of } \\
\text { acquiring as much outside input as possible from various communities that could contribute } \\
\text { to public policy development, including supply-side participants and their trade associations, } \\
\text { consumer groups, and the academic community. }\end{array}$ \\
\hline $\operatorname{Resp}$ & - The central bank should ensure that the systems it operates comply with the core principles. \\
\hline Description & $\begin{array}{l}\text { The BI oversight function has subjected itself and the RTGS to four self assessments since } \\
2005 \text { and two of these were given peer review by the HKMA and RBA. The BI's attention to } \\
\text { its oversight responsibilities and benchmarking to best practice through self assessments is } \\
\text { commendable. } \\
\text { The Payment Systems unit oversees the operations of the RTGS as an ongoing activity. }\end{array}$ \\
\hline Assessment & Broadly Observed \\
\hline Comments & In order to observe the issues relating to CPs not fully observed should be addressed. \\
\hline $\begin{array}{l}\text { Respo } \\
\text { operat }\end{array}$ & $\begin{array}{l}\text { The central bank should oversee observance with the core principles by systems it does not } \\
\text { uld have the ability to carry out this oversight. }\end{array}$ \\
\hline Description & $\begin{array}{l}\text { BI has defined the scope of its oversight under the core principles narrowly, including only } \\
\text { BI-RTGS in the ambit of its formal payment system oversight under the core principles. } \\
\text { The rapid development of the Indonesian financial system will raise the profile of a number } \\
\text { of payment and securities settlement systems. It is important that the BI oversight function } \\
\text { anticipate the expanding role of clearing and settlement systems in addition to the BI-RTGS }\end{array}$ \\
\hline
\end{tabular}




\begin{tabular}{|c|c|}
\hline & $\begin{array}{l}\text { and adjust the scope of its oversight interest accordingly. In this regard, the BI oversight } \\
\text { function needs to ensure that it has the appropriate types and amount of skills necessary to } \\
\text { perform an expanded set of responsibilities. }\end{array}$ \\
\hline Assessment & Partly Observed \\
\hline Comments & $\begin{array}{l}\text { In order to fully observe this principle BI needs to widen the scope of its oversight and } \\
\text { strengthen its activities through formal arrangements for oversight. }\end{array}$ \\
\hline \multicolumn{2}{|c|}{$\begin{array}{l}\text { Responsibility D - The central bank, in promoting payment system safety and efficiency through the core } \\
\text { principles, should cooperate with other central banks and with any other relevant domestic or foreign } \\
\text { authorities. }\end{array}$} \\
\hline Description & $\begin{array}{l}\text { The BI cooperates with other central banks in the region. It has also sought technical } \\
\text { assistance from other central banks. As operational linkages are established between the } \\
\text { Indonesian and other national or international payment systems, the BI oversight function } \\
\text { needs to ensure that it is well positioned to exercise its oversight responsibilities vis-à-vis } \\
\text { these systems. A current example is that which is planned with the HK dollar clearing system } \\
\text { for the PVP settlement of IRD/USD foreign exchange transactions. In this case, the BI's } \\
\text { cooperative oversight would include advanced consultations with the central bank of issue } \\
\text { for the foreign currency in question (the Federal Reserve System), and formal agreement } \\
\text { with the HKMA on the BI's participation in cooperative central bank oversight of the } \\
\text { privately operated settlement system in question. } \\
\text { Cooperation with other regulatory authorities is informal and not structured. }\end{array}$ \\
\hline Assessment & Broadly Observed \\
\hline Comments & $\begin{array}{l}\text { Cooperation with other domestic authorities and regulators could be improved and structured } \\
\text { by signing formal MOUs and creating joint working groups, when appropriate. This applies } \\
\text { to cooperation with other functions of BI (e.g. the Bank Supervision Department) and other } \\
\text { external authorities and regulators (e.g. Bapepam, and the telecommunications regulatory } \\
\text { authority). }\end{array}$ \\
\hline
\end{tabular}

